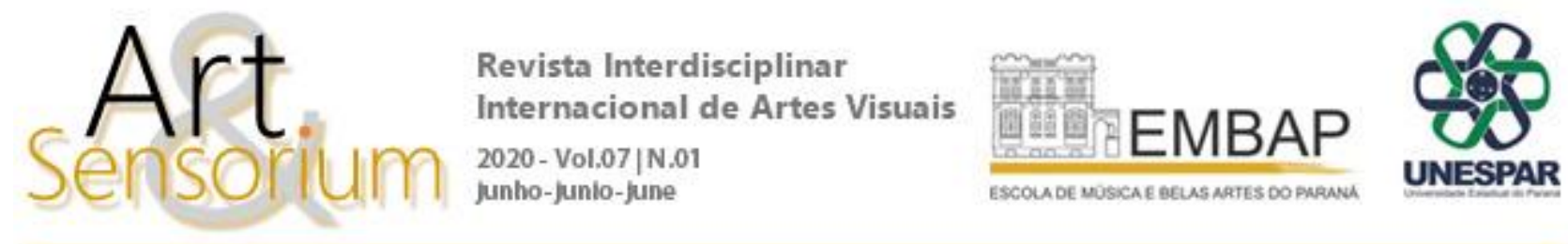

\title{
TRANSIÇÕES E EXPANSÕES DA ARTE NO MEIO DIGITAL: NOVAS REINTERPRETAÇÕES ALÉM DO TEMPO DO ARTISTA
}

\author{
DOI: https://doi.org/10.33871/23580437.2020.7.1.44-57
}

David Ruiz Torres ${ }^{1}$

\begin{abstract}
Resumo: As mediações tecnológicas realizadas na mostra "O encantado" desenhos, pinturas $e$ objetos de Attilio Colnago (2014) na cidade de Vitória (ES-Brasil), possibilitaram a abordagem do processo criativo do artista evidenciando o papel comunicativo da arte no meio digital. Considerandose as possibilidades dos novos recursos tecnológicos oferecidos na sociedade atual, as construções interativas dentro dos espaços de exposição constituem atualmente o melhor veículo para transmitir uma mensagem de grande força expressiva, como é o caso do processo criativo do artista.

Assim, os conteúdos digitais, disponibilizados mediante $Q R$-codes na sala de exposição durante este ensaio, possibilitaram uma abordagem do processo criativo do artista e o desenvolvimento de um diálogo entre a obra e o público além do tempo do artista ou da recepção da obra no espaço expositivo. Estabelecia-se, portanto, uma nova dimensão da obra do artista, na qual se multiplicava exponencialmente a mensagem intrínseca e comunicadora da arte mediante o uso das redes digitais que levavam o público para além da fisicalidade da galeria.
\end{abstract}

Palavras chave: arte; meio digital; $Q R$-codes; processo criativo.

\section{TRANSITIONS AND EXPANSIONS OF ART IN THE DIGITAL MEDIUM: NEW REINTERPRETATIONS BEYOND THE ARTIST'S TIME}

\begin{abstract}
The technological mediations carried out at the exhibition "O encantado" desenhos, pinturas e objetos de Attilio Colnago (2014) in the city of Vitória (ES-Brazil), allowed the approach of the artist's creative process, highlighting the communicative role of art in the digital environment. Considering the possibilities of the new technological resources offered in today's society, the interactive constructions within the exhibition spaces are currently the best vehicle to transmit a message of great expressive force, as is the case of the artist's creative process. Thus, the digital content, made available by QR-codes in the exhibition room during this essay, allowed an approach to the creative process of the artist and the development of a dialogue between the work and the audience beyond the time of the artist or the reception of the work in the exhibition space. In this way, a new dimension of the artist's work was established. The intrinsic and communicating message of art was multiplied exponentially using the digital networks that took the audience beyond the gallery's physicality.
\end{abstract}

Keywords: art; digital medium; QR-codes; creative process.

\footnotetext{
${ }^{1}$ Professor do Programa de pós-graduação em Artes - UFES. Doutor em Artes, especialidade em Patrimônio e Novas Tecnologias, pela Universidade de Granada (Espanha) com a teses doutoral "El papel de la realidad aumentada en el ámbito artístico-cultural: la virtualidad al servicio de la exhibición y la difusión” (2013), e Pós-doutorado (PNPD/CAPES) na Universidade Federal do Espírito Santo (ES-Brasil) com o projeto "Aplicação das novas tecnologias em museus do Brasil: novas ferramentas de difusão e interpretação do bem cultural”(2014-2019).dvdruiztorres@gmail.com
} 


\section{TRANSICIONES Y EXPANSIONES DEL ARTE EN EL MEDIO DIGITAL: NUEVAS REINTERPRETACIONES MÁS ALLÁ DEL TIEMPO DEL ARTISTA}

Resumen: Las mediaciones tecnológicas realizadas con motivo de la exposición "O encantado" desenhos, pinturas e objetos de Attilio Colnago (2014) en la ciudad de Vitória (ES-Brasil), permitieron abordar el proceso creativo del artista, destacando el papel comunicativo del arte en el medio digital. Considerando las posibilidades de los nuevos recursos tecnológicos ofrecidos en la sociedad actual, los recursos interactivos dentro de los espacios expositivos son actualmente el mejor aliado para transmitir un mensaje de gran fuerza expresiva, como es el caso del proceso creativo del artista. Por lo tanto, el contenido digital disponible a través de códigos QR en la sala de exposición durante esta propuesta, permitió un acercamiento al proceso creativo del artista y el desarrollo de un diálogo entre la obra y el público más allá del tiempo del artista o de la propia recepción de la obra de arte en el espacio expositivo. Por lo tanto, se establecía una nueva dimensión de la obra del artista, en la que el mensaje intrínseco y comunicativo del arte se multiplicó exponencialmente mediante el uso de las redes digitales que llevaron al público más allá del espacio físico de la galería.

Palabras clave: arte; medio digital; códigos QR; proceso creativo.

\section{Introdução: expansões da arte no meio digital}

A sociedade do início do século XXI experimenta uma época de mudanças sem precedentes, tanto pela sua velocidade quanto pelo tipo, que estão causadas e/ou aceleradas pela presença da tecnologia digital e computacional em todas as esferas de nossa vida cotidiana. Isto é algo que percebemos desde a última década do século passado e que continua se produzindo como um processo progressivo que supõe o aparecimento de uma nova época, a qual tem recebido o nome de cibercultura por vários autores contemporâneos.

Esta nova etapa em que estamos engajados exigiu uma revisão e redimensionamento das formas de compreender as práticas sócio-culturais, levando efetivamente à sua classificação em dois grandes padrões culturais, demarcando uma cultura da presença e outra da interface digital; sendo, esta última, aquela que tem sido classificada como cultura digital ou cibercultura. Assim, para autores como Pierre Lévy, a cibercultura representa "o conjunto de técnicas (materiais e intelectuais), de práticas, de atitudes, de modos de pensamento e de valores que se desenvolvem juntamente com o crescimento do ciberespaço" (2000, p. 17).

Uma definição mais completa e abrangente estaria nas palavras de Lucia Leão, quando descreve o que seria esse mencionado ciberespaço o qual seve como marco inseparável do aparecimento da recente cibercultura. A autora nos dirá que o ciberespaço:

engloba as redes de computadores interligadas no planeta (incluindo seus documentos, programas e dados); as pessoas, grupos e instituições que participam dessa interconectividade e, finalmente, o espaço (virtual, social, informacional, cultural e comunitário) que emerge das inter-relações homens-documentosmáquinas (2004, p. 9).

Portanto, quando nos referimos aos conceitos de cibercultura ou ciberespaço devemos ter presente a configuração da natureza do universo ao qual pertence nossa sociedade e que afetam, necessariamente, ao nosso pensamento e à maneira de como enfrentar a realidade.

Isto nos mostra como a mudança cultural que estamos vivenciando não apenas supõe uma presencia da tecnologia e do digital com a inserção de novos dispositivos em nossa cotidianidade, senão, que evidencia uma nova forma de pensamento que acompanha essas mudanças e que, em grande parte, é causa do desenvolvimento de uma nova etapa cultural. Certamente, a cibercultura implica em uma 
importante mudança de mentalidade, nos modos de percepção e mediação dos fenômenos, que afeta a muitos âmbitos destacando especialmente a pesquisa e as construções científicas, a transmissão e aquisição de conhecimentos, as estratégias de aprendizagem na educação, e os processos de criação literária e artística.

Sem dúvida, os mencionados processos de criação têm sido modificados enormemente no referente a sua gênesis, materialização, divulgação e fruição, se estabelecendo duas esferas, a do espaço físico e a do mundo digital, que se combinam inseparavelmente. Assim, o computador se converte em uma ferramenta fundamental para grande parte dos autores e artistas que acompanha a obra desde o ato criador. Os tradicionais documentos de processo rascunhos, esboços e croquis (numa versão analógica digitalizada ou mesmo inteiramente digitais) se encontram armazenados na memória digital do dispositivo pessoal e aqui são editadas, compartilhadas ou copiadas com todas as novas possibilidades que a flexibilidade e plasticidade do meio digital permite até a data.

Quando em_não contem com o fim do livro, o autor italiano Umberto Eco foi perguntado sobre os livros que tentaria salvar caso que fosse declarado um incêndio em sua casa, ele não duvidou em responder que salvaria o HD do seu computador com os escritos dos últimos trinta anos (2010, p. 38). Esta referência anedótica de Eco nos mostra a importância dada aos novos médios digitais como ferramenta no ato criador e como lugar de armazenamento massivo das informações.

Mas, aparentemente, o mais importante legado que o meio digital nos oferece vem como consequência do aparecimento da Internet e a materialização do que era chamado como ciberespaço, que nas palavras de Pierre Lèvy era definido como um "espaço de comunicação aberto pela interconexão mundial dos computadores e das memórias dos computadores" (2000, p. 94). Assim, a Internet se constitui como uma comunidade global que quebra as fronteiras físicas tradicionais, possibilitando um espaço supostamente mais democrático para o aceso e a circulação das informações (não ignoramos aqui a manipulação e a centralização dos provedores de internet). Isto levou à uma nova forma de acesso ao conhecimento através do nosso computador ou dispositivo eletrônico pessoal, facilitando a obtenção de um conhecimento mais amplo e mais diversificado, além de mais velocidade e imediatismo que são intrínsecos às características da sociedade digital, o que definitivamente acelerou os nossos modos de relação e recepção dos fenômenos do mundo sensível.

Com o aumento da interação entre pessoas de todo o mundo, se produzirá um forte impacto nos processos de criação na arte já que o ciberespaço integra-se ao pensamento estético atual, no qual o indivíduo não se limita, necessariamente, aos limites do mundo físico.

Assim, desde a década de noventa do século XX, encontramos diferentes manifestações da arte que se baseiam no meio digital como elemento comunicador no qual expressar a poética do artista. A web arte, a arte virtual, a software art, ou a arte telemática, são mostras consolidadas desta prática contemporânea na qual o elemento físico e intrínseco à obra de arte tradicional desaparece e está configurado digitalmente.

Outra das contribuições do meio digital no processo de produção da obra de arte, tem sido o caráter aberto do mesmo ato criador. Umberto Eco consideraria isto já em "Obra aberta" (1962), o que parece levar à uma atividade de co-autoria na qual estão presentes tanto o autor como o público no mencionado ato criador. Julio Plaza (2003) estabeleceria, assim, os diferentes graus de participação na obra de arte, sendo o terceiro grau aquele que corresponderia com a arte digital na qual não falaríamos de interpretação ou de participação senão de interação com a obra, aparecendo em cada uma dessas intervenções/interações uma nova dimensão do trabalho não concebida pelo artista e sim pelo indivíduo receptor da obra.

Da mesma forma que no âmbito da escrita, o artista tem aproveitado as possiblidades do computador como uma ferramenta fundamental no processo de trabalho, pois, é evidente que nossa sociedade se encontra mediatizada pelas redes e interconexões que falávamos anteriormente e que convertem nossa realidade num cenário de hibridação entre o mundo físico e o mundo digital/virtual. Por tanto, quando 
nos encontramos diante da obra de arte, estamos no final do caminho do processo criativo do artista no qual também nos deparamos com uma nova situação na qual as ferramentas digitais formam parte deste processo antes, durante e depois do ato criador. A pesquisadora Cecilia Almeida Salles é ciente desta mudança mediatizada pelo meio digital quando comentava sobre a pesquisa do processo criativo que:

Algumas obras, incluindo todo o potencial que as mídias digitais oferecem, parecem exigir novas abordagens. Ao mesmo tempo, muitas dessas obras exigem novas metodologias de acompanhamento de seus processos construtivos e não somente a tradicional coleta de documentos, no momento posterior à apresentação da obra publicamente, isto é, a abertura das gavetas dos artistas para conhecer os registros das histórias das obras (2007, p. 46).

Assim, na contemporaneidade, tanto por meio do desenvolvimento tecnológico, quanto por meio das artes, tem sido redesenhada essa relação e suas consequências, promovendo novas práticas nas quais a criação e fruição da arte tem ampliado enormemente suas possibilidades mediante a utilização das novas ferramentas tecnológicas.

Este conjunto de considerações foram as que levaram a uma colaboração com a mostra " $\mathrm{O}$ Encantado", desenhos, pinturas e objetos de Attilio Colnago, uma mostra homônima do artista capixaba que aconteceu na cidade de Vitória (ES), em 2014/2015, no Espaço Cultural Palácio Anchieta. Os objetivos principais desta participação conjunta consistiram em estabelecer uma experiência piloto no estado, baseada em uma mediação tecnológica com a obra de arte na qual se estabeleceria uma rede de diálogo entre a própria obra, o processo criativo, os documentos do processo criativo do artista e, sem ser menos importante, o público.

\section{Mediação digital e abordagem do processo criativo do artista}

As mediações digitais nos espaços expositivos têm sido consideradas em grande parte dos centros das artes no Brasil como uma ferramenta útil e com possibilidades para aproximar os objetos culturais a um público ainda maior. Apesar desta realidade recente, podemos constatar que o Espírito Santo carecia de experiências similares que mostrassem a versatilidade das novas tecnologias digitais como mediação nesses espaços. Isto foi o que levou a realizar uma experiência de carácter inédito no estado, a qual pretendia avaliar pertinentemente as possibilidades das mencionadas mediações digitais entre o público capixaba e a obra de arte, bem como apresentar ao povo capixaba uma outra forma de utilizar-se das redes sociais e dos meios digitais para a promoção de outra dimensão de recepção da obra nos espaços expositivos.

A capacidade de acessar à mente criativa do artista e compartilhar a gêneses da obra mediante os novos formatos digitais, foi o que levou à curadoria da Sala da Memória, um dos espaços nesta grande mostra retrospectiva da obra do artista Attilio Colnago. Aqui se realizaram duas edições fac-similadas dos cadernos de estudos do artista, com desenhos e esboços que fazem parte do seu processo criativo, permitindo nos adentrar na gênese de sua poética (Figuras 1 e 2). 


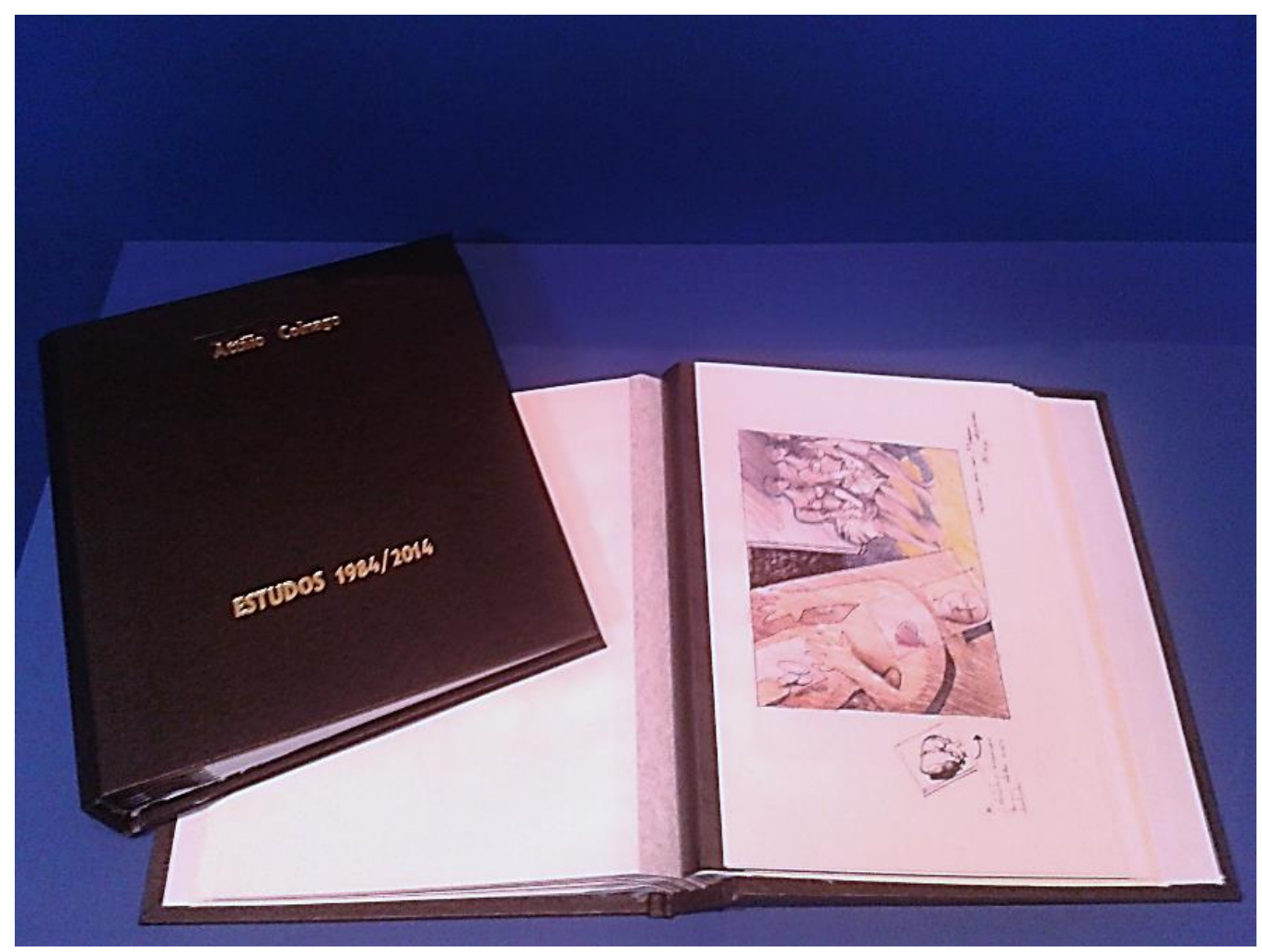

Figura 1. Exposição "O Encantado”, desenhos, pinturas e objetos de Attilio Colnago. Sala da Memória. As duas edições fac-similadas dos cadernos de estudos do artista poderiam ser observadas pelos visitantes da mostra. Foto do autor. 2015.

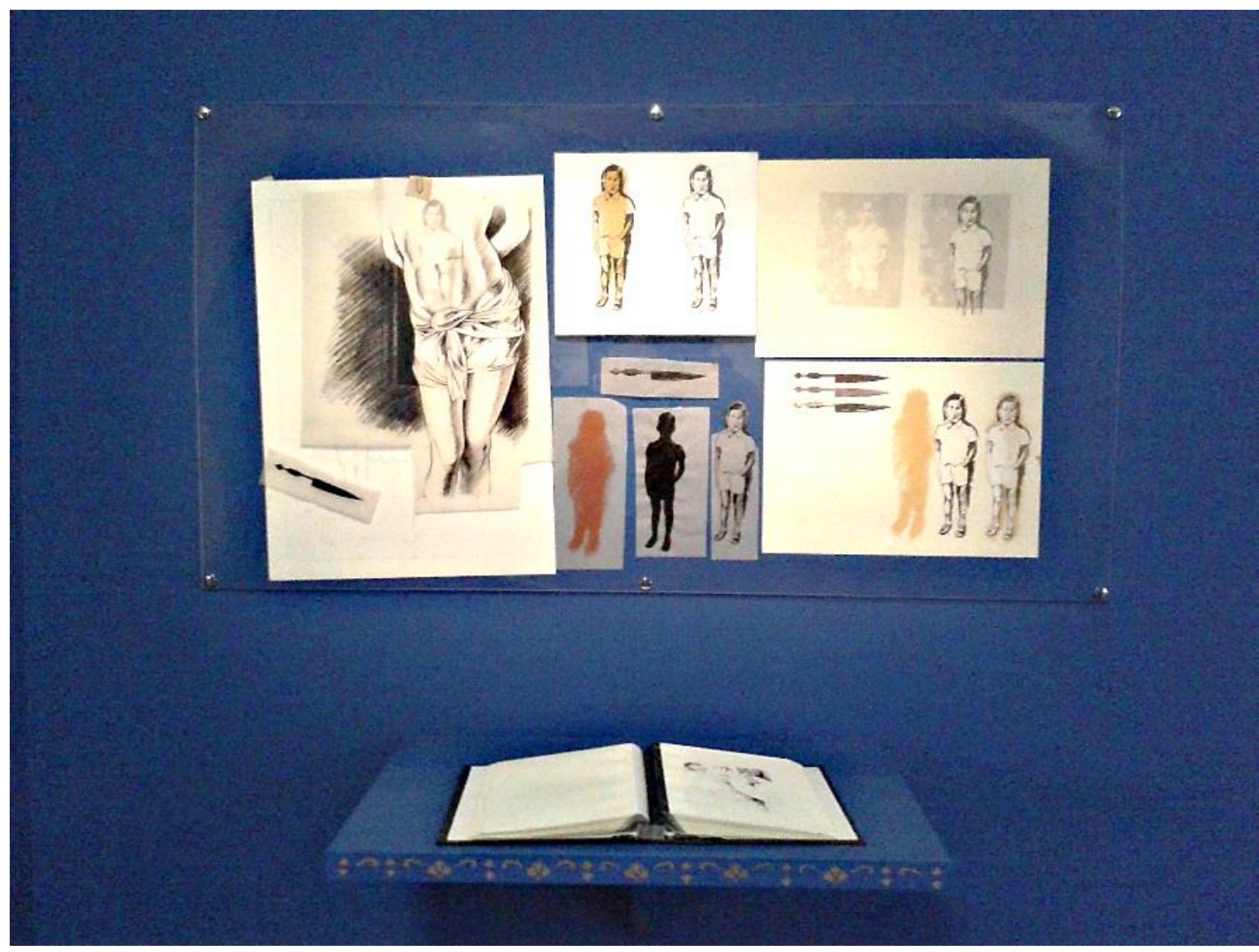

Figura 2. Exposição "O Encantado”, desenhos, pinturas e objetos de Attilio Colnago. Sala da Memória. Alguns dos documentos originais do processo criativo do artista foram expostos junto com as edições facsimiladas dos cadernos de estudos. Foto do autor. 2015.

R. Inter. Interdisc. Art\&Sensorium, Curitiba, v.7, n.1, p. 044 - 057 Jan.- Jun. 2020 
Isto permitiu ter aceso ao momento prévio da obra de arte, pois, na sala de exposição nos encontramos com a obra final, aquela que é resultado das (re)construções no imaginário do artista e que raramente são mostradas ao público. A importância de mostrar a parte do processo criativo junto com a obra resulta ser algo primordial para entender a poética do artista, sempre complexa, e estabelecer uma inter-relação mais fluida entre o artista e público receptor. Como bem expressa José Cirillo:

[...] esses documentos ampliam a própria capacidade da mente criadora de gerar novas imagens e obras, que eles aprimoram o funcionamento e, muitas vezes, aceleram o processo de gênese de uma obra por apresentarem possibilidades antes experimentadas pelo artista em outros momentos de seu projeto poético. De modo geral esses documentos seriam uma extensão da mente criadora do artista (2009, p. 23).

Considerando o importante papel de mostrar o processo criativo do artista, a proposta de curadoria na Sala de Memória contou com o uso das novas tecnologias digitais para ampliar os documentos, desta vez digitalizados, que estavam presentes na gênese dos trabalhos do artista. Assim, junto aos fac-símiles dos cadernos de estudos, foram disponibilizados os "cadernos virtuais" em três telas interativas de led localizadas na mesma sala que podiam ser acionados ao toque na tela. Estes "cadernos virtuais" permitiam o acesso a uma grande quantidade de imagens digitais procedentes dos cadernos de estudo possibilitando, de este modo, ampliar o espaço físico por meio de sua reprodução digital.

A mediação do digital mediante os "cadernos virtuais" permitiu disponibilizar uma grande quantidade de documentos, mais além dos documentos originais que estavam na sala, aumentando, assim, o próprio espaço expositivo e as possibilidades de nos aproximar do processo criativo do artista. Ainda, estas possibilidades se tornaram mais interessantes, pois quando falamos da interação com o meio digital, através das telas sensíveis ao toque, se fomentava a capacidade participativa que é fundamental nos meios educativos junto com a interatividade. Assim, a possiblidade de interatuar com informações digitais parece conseguir características que se encontram dentro das estratégias de desenvolvimento da aprendizagem. Isto é manifestado por Daniela Kutschat que nos diz: "com o digital, os modelos de visualização e de tangibilização de informações parecem se aproximar de processos cognitivos que envolvem o raciocínio, a memória, a experiência, o aprendizado e os afetos" (2014, p. 275).

Fomentando o acesso a este conjunto de documentos digitais, por meio dos dispositivos eletrônicos, se pretendia promover a construção autônoma do conhecimento e, finalmente, conseguir um envolvimento mais significativo e ampliado do visitante na obra do artista, objetivos estes que foram perseguidos na configuração da Sala de Memória, ainda que, como em qualquer atividade interativa quando nos referimos ao digital, o nível de profundidade dependerá do visitante participante e, portanto, do desejo individual de conhecimento exigido dentro da sala. Assim, a tecnologia digital promovia um novo modo de relacionar-se com a vivencia do objeto estético, pois, mesmo que os desenhos disponibilizados tivessem uma edição anterior, a sobreposição de três telas interativas, que acessavam três conjuntos diferentes de projetos, garantiam a cada visitante uma experiência impar e quase impossível de se repetir.

\section{A gênesis criativa do artista no (ciber)espaço expositivo}

Como avançávamos anteriormente neste texto, a Internet como principal paradigma do ciberespaço (sem esquecer dos novos dispositivos que permitem interagir com o meio digital), tem sido um aliado primordial para uma nova relação entre o artista, a obra e o público nos espaços expositivos do século XXI. A obra de arte, em sua intrínseca função comunicadora, é novamente chave para a consolidação deste novo modo de agir com as práticas e experiências culturais; ela, a arte, toma para si a capacidade 
de levar ao público, graças ao uso dessas novas tecnologias, à promoção de um diálogo com a obra e o artista.

É por isto que, além da mediação proposta na Sala da Memória, se considerou importante mostrar o processo criativo das obras da exposição mais além do espaço físico disponibilizando uma série de conteúdos digitais referentes ao processo, permitindo ter as fases prévias e vislumbrar aquele quebracabeças que conformava a obra final e que nos é mostrado, de forma fragmentada, na sala expositiva. Esta visão ampliada da obra de arte é algo onde o papel das novas tecnologias digitais tem um papel fundamental e oferecem um grande potencial para o estudo do processo criativo do artista e, em definitiva, um conhecimento mais próximo da obra de arte. Esta ideia é compartilhada por Cecilia Salles quando afirma que:

[...] o debate sobre a produção artística mediatizada pelas tecnologias digitais recai, em muitos casos, sobre questões que envolvem o processo de criação. Em alguns casos, a arte contemporânea nos faz questionar as histórias das construções das obras, preservadas nos arquivos dos artistas, materiais e/ou virtuais; mas não só, pois muitas vezes as obras que vemos inviabilizam a segmentação da história de sua construção, e aquilo que é mostrado publicamente (2012, p. 525).

Até a data, são muitas as ferramentas digitais disponíveis que, despendendo das necessidades de cada espaço expositivo e o discurso que se pretende transmitir, são adaptadas e usadas para acompanhar ao público durante a visitação. Em nosso caso, nesta segunda parte do ensaio, foram escolhidos os QR-codes como elemento fundamental de interação entre os visitantes e os conteúdos digitais que foram disponibilizados especialmente para a exposição.

O QR-code é um código de barras bidimensional para ser usado a partir de telefones celulares equipados com câmera. Esse código nos daria acesso a informações digitais multimídia que se encontram hospedadas na Internet, permitindo estabelecer um nexo entre o espaço físico e o ciberespaço. Outra de suas características seria estabelecer uma interatividade com os visitantes, através dos dispositivos celulares, que ampliaria a informação sobre o local ou objeto no qual está aplicado (Figura 3). 


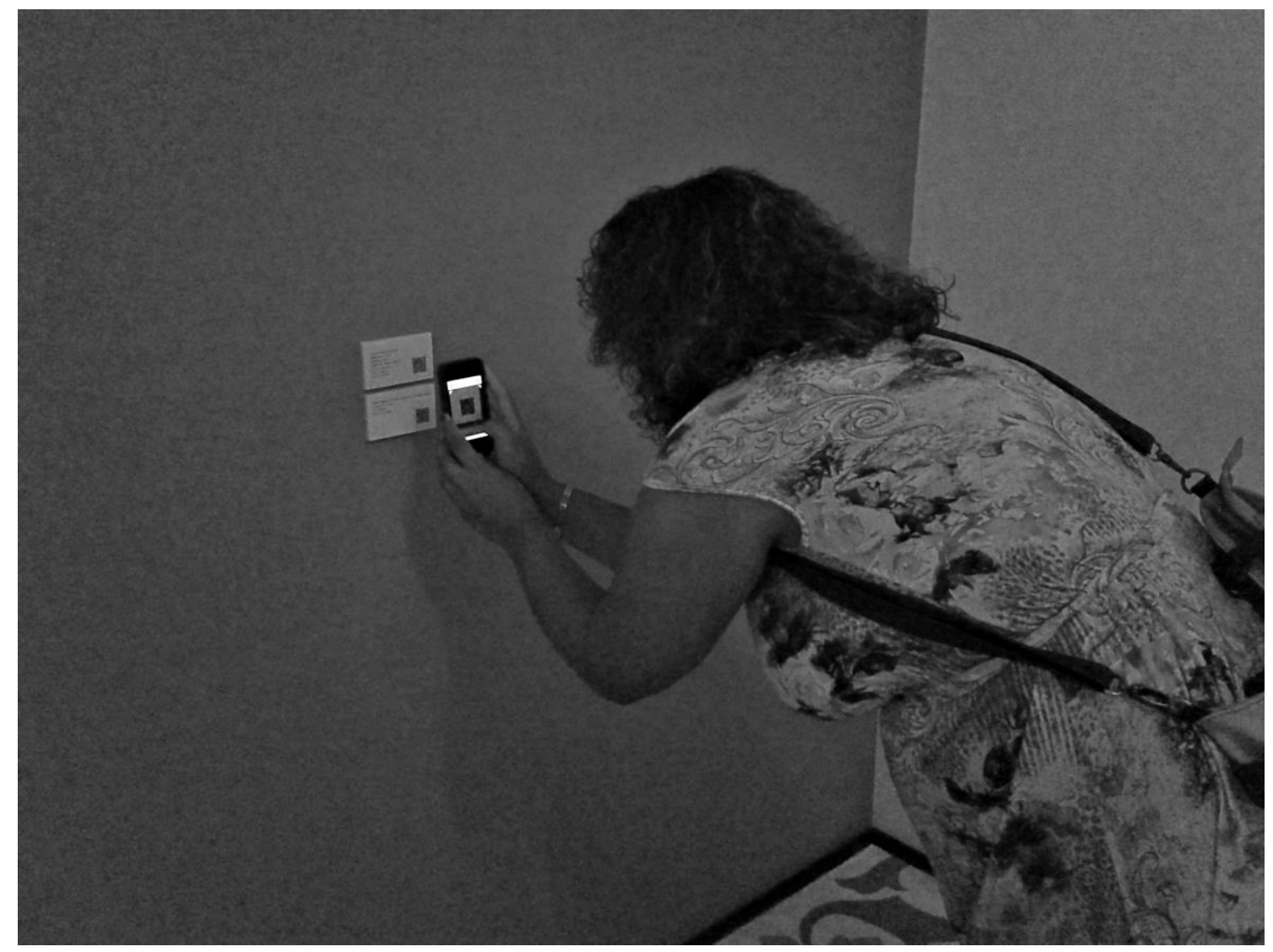

Figura 3. Exposição "O Encantado", desenhos, pinturas e objetos de Attilio Colnago. Visitante escaneando com o celular pessoal o QR-code sobre uma das obras da mostra. Foto do autor. 2014.

A presencia cada vez maior dos dispositivos celulares tem nos permitido uma aproximação ao mundo digital/virtual, agora coabitante de nosso ambiente, e que antes se limitava unicamente à tela de nosso computador. Assim, a tela do nosso celular se torna, atualmente, em um ponto de acesso primordial do chamado homo ecranis (Lipovetsky e Serroy, 2009) que está presente em nosso cotidiano. É por isto que no âmbito artístico estes meios de mediação estética estão cada vez mais presentes, não apenas como um dos suportes da arte digital, mas também como um meio de difusão, de acesso e interação com obra de arte, para além da sua fisicalidade nos espaços expositivos.

A escolha dos QR-codes como ferramenta para uma mediação digital não foi por acaso, senão que especialmente resulta ser um dos recursos mais utilizados no Brasil. Assim, tem sido utilizado nos últimos anos em grandes centros expositivos como na exposição "Salvador Dalí", no Instituto Tomie Ohtake em São Paulo (2014/2015); na 31 a Bienal de São Paulo (2014); na mostra "Mondrian e o movimento de Stijl", no Centro Cultural Bando do Brasil do Rio de Janeiro (2016/2017); ou na "Guia multimídia" do Memorial Vale, em Belo Horizonte, por citar alguns exemplos do eixo do sudeste, no qual se encaixa o Espírito Santo. Isto evidenciaria uma prática atual e ainda vigente que resulta ser consequente com a sociedade digital na que nos encontramos imersos e que comentávamos anteriormente.

Também devemos destacar que a obra do artista capixaba Attilio Colnago, que centrava a nossa experiência, tornava-se especialmente relevante em referência ao papel comunicativo da arte. Os trabalhos do artista se apresentam como uma visão hibrida que combina elementos da memória pessoal do artista, assim como imagens icônicas da história da arte, espacialmente dos metres italianos do Renascimento, que remetem também à sua ascendência italiana (Figura 4). As diferentes alusões ao mundo da infância, às tradições culturais italianas, à sua região natal no interior do estado, ou as 
referências ao catolicismo permeiam os trabalhos do artista. Além disso, os grandes mestres da história da arte europeia se mostram em novos contextos, como uma iconografia atemporal, superando o momento e significação da obra original, revelando um certo citacionismo como tendência do projeto poético do artista. Uns desdobramentos que remanescem na mente durante o processo criativo, e que precisam de uma leitura compartilhada entre o artista e o público. José Cirillo comenta a importância de este ato comunicador quando nos diz que:

O entendimento das relações comunicativas que envolvem o processo de criação dá visibilidade a ações da mente do artista e aos diálogos por ela estabelecidos, o que parece poder tornar possível uma aproximação com essa outra dimensão da obra exibida ao público: as incertezas e a (in)completude evidenciadas nos documentos do processo, na gênese da obra de arte $(2009$, p. 26).
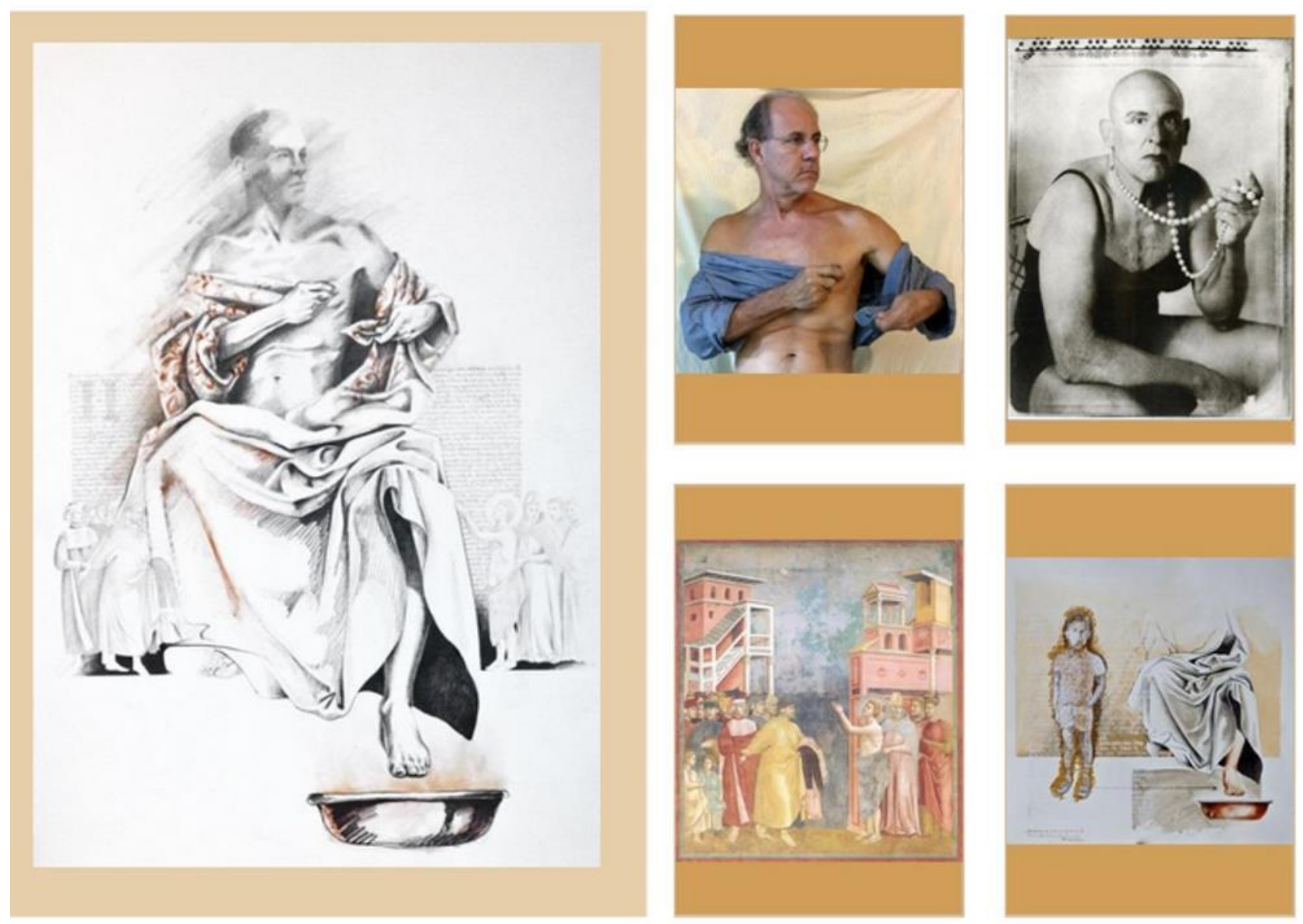

Figura 4. Attilio Colnago, Humilitate (2014). Conteúdo digital do QR-code sobre a obra Humilitate (à esquerda) e documentos do processo criativo (à direita). Podemos observar estúdios de fotografia do próprio artista, referências como o trabalho fotográfico "Rose" de Joy Goldkind (2000/2013) ou um afresco do mestre italiano Giotto com o tema de São Francisco renunciando aos Bens Terrenos (c. 1290-1300) que participaram como referentes imagéticos na construção do trabalho final do artista. Também se oferecia a possiblidade de comparar outras obras do artista como foi "Anotações de verão com pé de Cristo" (2013) na que apareciam rascunhos que seriam usados em um trabalho posterior. Captura de tela pelo autor.

As possibilidades de estabelecer uma interatividade entre o público e o processo criativo da obra de arte expandindo o espaço físico da mostra sobre o artista Attilio Colnago em Vitória a través dos QRcodes e do celular pessoal, oferecia enormes possibilidades no estudo tanto da imagem como da cultura icônica contemporânea que reforçava a pertinência do ensaio proposto. Assim, o uso dessas tecnologias pelos espaços expositivos atuais nos permite ter uma aproximação da obra oferecendo

R. Inter. Interdisc. Art\&Sensorium, Curitiba, v.7, n.1, p. 044 - 057 Jan.- Jun. 2020 
uma visão ampliada a través do espaço digital. Os conteúdos que eram mostrados aos visitantes da mostra que acessavam aos QR-codes, foram hospedados em um site ${ }^{2}$ que recolhia informações digitais com textos explicativos e com a documentação do processo criativo do artista. Deste modo, conseguíamos nos aproximar desses elementos da memória pessoal do artista e dos grandes mestres da pintura que indicialmente inspiraram as obras mediante a constituição de um (ciber)espaço expositivo que tornava o ato fruidor da obra da arte em um ato híbrido entre o espaço físico da mostra e seu prolongamento digital/virtual (Figuras 4 e 5).

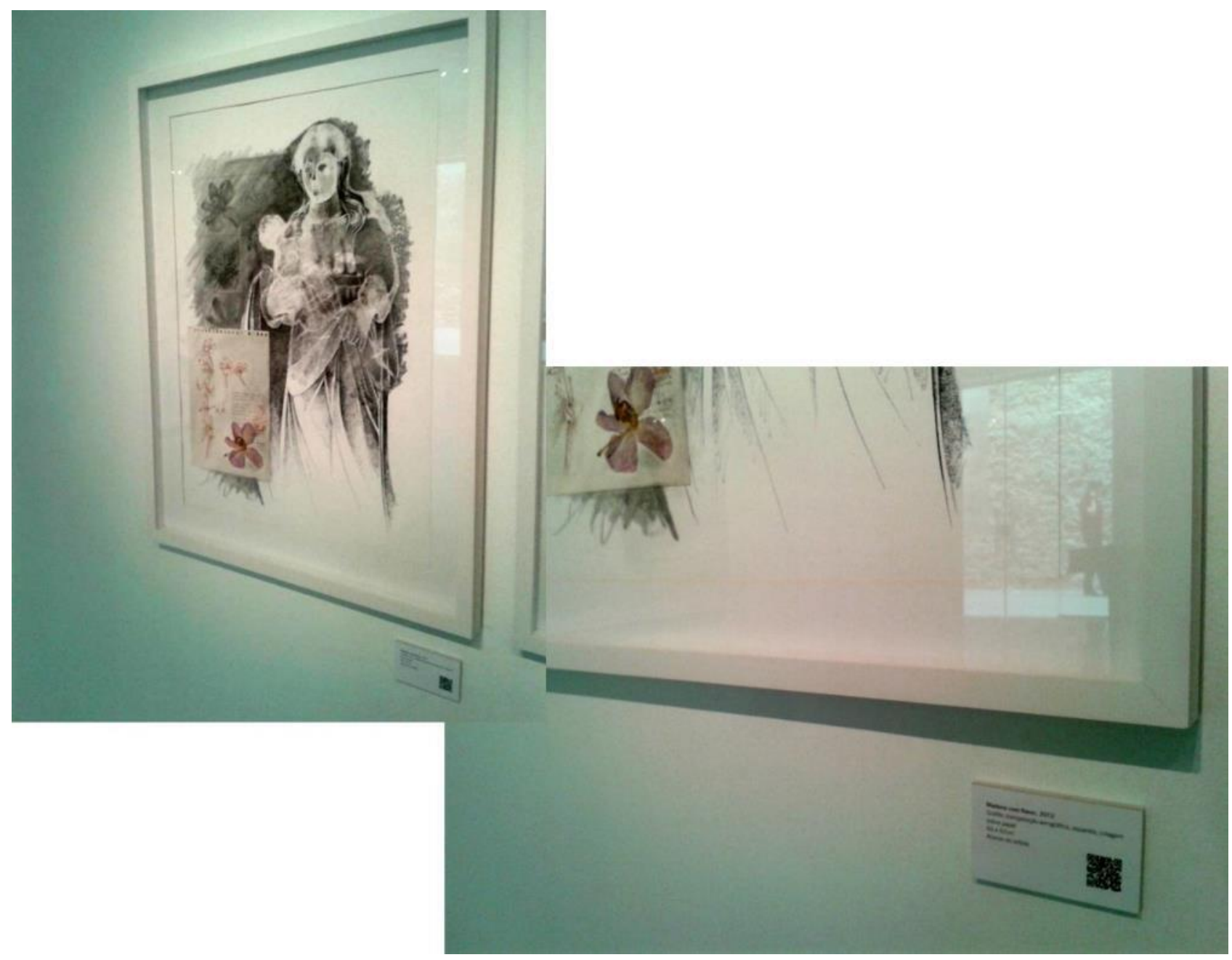

Figura 4. Attilio Colnago, Madona com flores (2012). Trabalho do artista na sala de exposição com etiqueta do QR-code para acessar os conteúdos digitais. Foto do autor. 2015.

\footnotetext{
${ }^{2}$ Site com os conteúdos digitais dos QR-codes de mostra: <http://attiliocolnago.wixsite.com/oencantado >
}

R. Inter. Interdisc. Art\&Sensorium, Curitiba, v.7, n.1, p. 044 - 057 Jan.- Jun. 2020 

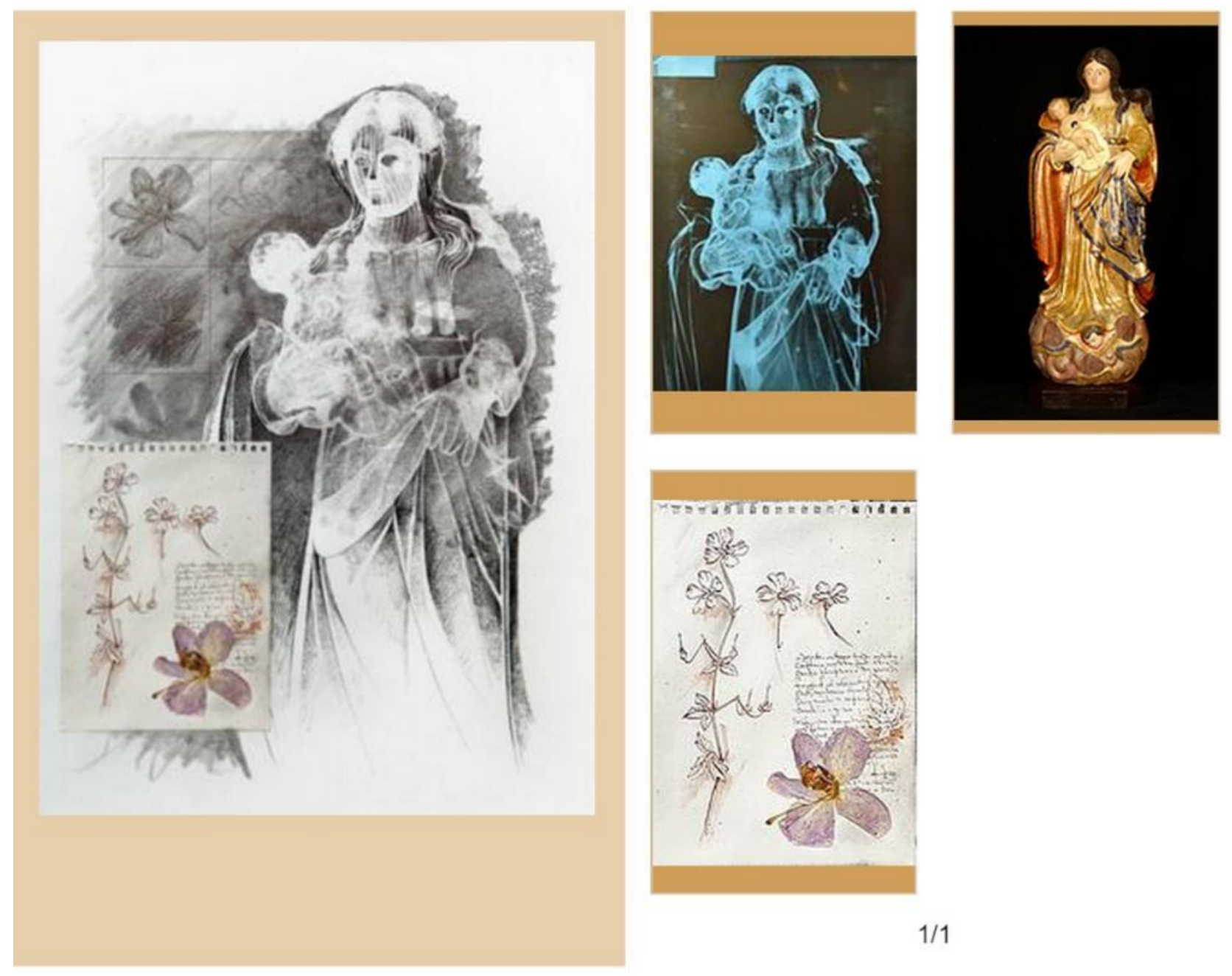

$1 / 1$

Figura 5. Conteúdos digitais do trabalho Madona com flores (2012). Aqui mostram-se diferentes documentos do processo criativo do artista como uma radiografia resultado do trabalho de restauração realizado pelo próprio artista da imagem religiosa de Nossa Senhora do Amparo da localidade capixaba de Itapemirim (ESBrasil). Podemos perceber que os trabalhos do artista são uma visão híbrida de um conjunto de referências visuais como um detalhe dos desenhos de uma orquídea do artista Leonardo da Vinci e uma orquídea dissecada na folha de papel que se tornaram como parte importante do resultado final do trabalho. Captura de tela pelo autor.

Esta ideia de expandir os limites físicos do espaço expositivo, no qual encontramos a obra final, buscava tornar possível aumentar, por meio das novas tecnologias digitais, a experiência sensível do público, o que nos faz participantes do ideal de André Malraux, em seu texto $O$ museu imaginário (1947), que, como precursor da ideia de um acervo em Rede, supõe a existência de um imenso cibermuseu no qual se reúnem todas as expressões da arte, todos os estilos, todos os artistas... em uma grande sala de exposição que tem como cenário a Internet e o meio digital. Estes conceitos colocados por Malraux poderiam ser extrapolados aos documentos que são parte do processo criativo do artista, pois, levam a uma nova compreensão da obra; os bosquejos, os rascunhos ou os ensaios, entre outros, nos permitem ter essa visão ampliada que conforma um contexto excepcional para entender a obra de arte a través do paradigma do meio digital.

A importância deste fato foi evidenciada na experiência, coordenada por Cecilia Almeida, de construção do blog redesdacriacao.org.br do Itaú Cultural, o qual pretendia constituir um registro dos 
documentos existentes na Rede, assim como um instrumento de pesquisa sobre o processo de criação online. Aqui, se recolhia em umas das suas postagens o seguinte:

Está aumentando a quantidade de documentos de processo, das mais diversas áreas, que estão sendo disponibilizados na internet. $O$ fácil acesso e a qualidade das imagens oferecem novas possibilidades de pesquisas a partir de cadernos, cartas, rascunhos etc. A maneira como os sites estão organizados, na maioria dos casos, facilitam o estabelecimento de relações entre os diferentes documentos. Pode-se, assim, saber mais sobre os processos de criação da arte, da literatura e da ciência ${ }^{3}$.

Deste modo, como bem as denomina Pierre Lévy, "as tecnologias da memória” no livro do mesmo título (1990), nos possibilitaram o acesso a um grande arquivo em rede no qual se reúnem e se interligam todos os saberes da cultura. Esta associação entre arquivo e memória não é estranho ao meio, pois no mesmo surgimento da Internet, baseada no hipertexto como uma nova maneira de administrar e organizar a informação, se utilizou o termo Memex (MEMory EXtender $)^{4}$ para se referir a esta nova forma de navegar pelo ciberespaço; relacionando-o com a maneira de funcionamento do cérebro, por associação, e estabelecendo assim, um paralelo com a máquina para descrever a esta nova extensão da memória humana.

\section{Considerações finais}

Certamente, e como comentávamos desde o início do texto, o meio digital tem sido caracterizado como uma grande fonte de informações na qual todos os usuários participam de um conhecimento universal que se retroalimenta e gera novos nós do saber. Assim, a ideia do ciberespaço como um repositório da memória cultural, também é mostrada no pensamento de Pierre Lévy, quando fala dele como o lugar no qual a memória dos homens se expande e se mostra para tudo o conjunto da sociedade:

Eis o ciberespaço, a pululação (sic) de suas comunidades, a ramificação entrelaçada de suas obras, como se toda a memória dos homens se desdobrasse no instante: um imenso ato de inteligência coletiva sincrônica, convergindo para o presente, clarão silencioso, divergente, explodindo como una ramificação de neurônios $(2000$, p. 260).

Neste momento merece ser observada a ideia de extensão da memória que estamos comentando em relação ao meio digital e ao estudo do processo criativo do artista, pois, tendo em consideração estas ideias sobre a memória do ciberespaço, a experiência com os QR-codes no espaço expositivo, justifica-se além do simples uso como um recurso vanguardista de mediação. De tal modo, nos conteúdos digitais hospedados na Rede, há inumeráveis referências que aludem à memória cultural do artista, seja através dos grandes mestres da história da arte, como a experiência pessoal do artista, mas também ensaios fotográficos prévios, bosquejos, rascunhos, anotações..., elementos todos estes, que formaram parte na consecução da obra final e que aparecem registrados, analógica ou digitalmente, como documentos do processo criativo. Estes documentos têm sido considerados por José Cirillo como uma extensão da mente do artista sendo um verdadeiro desdobramento do gênio criador no processo construtivo no qual estes:

\footnotetext{
3 S/A. Site com documentos de processo de criação, 2010. Disponível em: $<$ http://redesdecriacao.org.br/indexeb91.html?p=207>. Acesso em: 18 Nov. 2019.

${ }^{4} \mathrm{O}$ Memex (MEMory EXtender ou "extensor de memória" em português) foi uma máquina visionária imaginada pelo cientista americano Vannevar Bush no célebre artigo seminal intitulado As We May Think de 1945 que mostrava a possiblidade da máquina auxiliar nos processos mentais da memória de do conhecimento.
}

R. Inter. Interdisc. Art\&Sensorium, Curitiba, v.7, n.1, p. 044 - 057 Jan.- Jun. 2020 
acompanham o processo de criação, agilizando, ampliando e transformando a ação da mente criadora. Eles permitem à mente visualizar [...], partes do processo de elaboração da obra que é uma extensão do pensamento criador no seu processo de publicidade. Evidencia-se, novamente, um caráter comunicativo nessas extensões do corpo criador $(2009$, p. 27).

Desta forma, as extensões do ente criador do artista, através das mediações tecnológicas da mostra "O Encantado" que utilizavam as redes digitais, pretenderam conseguir um efeito multiplicador no processo comunicador destes documentos como extensão da mente/memória do artista. As redes digitais permitiriam mostrar a narrativa do processo criativo mais além da materialidade e finitude do tempo do artista estabelecendo um espaço de exibição ilimitado no espaço e no tempo através do ciberespaço.

O potencial do meio digital apareceria como o principal aliado para perpetuar a mensagem intrínseca e comunicadora da arte, representada em uma sobrevivência da memória comunicativa do artista, além de um desdobramento da sua obra em nosso presente, conseguindo uma durabilidade que transita e ultrapassa o tempo do artista como um legado para as gerações futuras ampliando o papel mediador da arte na cultura.

Deste modo, a experiência sobre o processo criativo através dos meios digitais desenvolvida na cidade de Vitória, permitiu ao público capixaba o acesso a estas correlações e mediações do próprio artista em seu processo criativo, ampliando e redimensionando as possibilidades do desenvolvimento de um diálogo que se produz entre a obra, o artista e o público. Assim, junto à obra final na sala de exposição, eram mostrados dois tempos da obra de arte e do gênio criativo do artista no mesmo espaço, acrescidos de uma outra dimensão, expandida pelo espaço digital que forneceria uma nova dimensão dialogante com a comunidade global de usuários.

Finalmente, com este ensaio, assistiríamos a uma nova forma de ver a obra no (ciber)espaço expositivo que ficaria distante das convicções expositivas do século XIX e pelas que a "aura" da obra de arte, como nos clarificava Walter Benjamin (1936), nos conduziria apenas a uma passiva e limitada admiração do gênio criador. Na sociedade atual, que está imersa na recente etapa da cibercultura, os meios tecnológicos nos oferecem, através de suas potencialidades e desdobramentos, uma nova visão do mundo na qual o papel comunicador da arte possui as melhores oportunidades para nos mostrar, mais que nunca, um efeito efetivo de mudança. $O$ processo de interatividade com uma mostra expositiva procura evidenciar e dar visibilidade ao potencial transformador da mediação arte e tecnologia e, em última instancia, nos questionar sobre este tipo de processos curatoriais que levariam a uma arte mais social cujo acesso prometeria ser mais diversificado e, em definitiva, expansivo.

\section{Referências}

CIRILLO, José. Arqueologias da criação: tempo e memória nos documentos de processo. In: CIRILLO, José; GRANDO, A. Arqueologias da criação: ensaios sobre o processo de criação. Belo Horizonte: C/Arte, 2009, p. 13-40.

ECO, Umberto e CARRIÈRE, Jean-Claude. não contem com o fim do livro. Rio de Janeiro: Record, 2010.

KUTSCHAT, Daniela. Visualização de dados e "tangibilização" da informação: una questão cognitiva. In: BEIGUELMAN, Giselle e MAGALHÃES, Ana Gonçalves (Orgs.). Futuros possivveis. Arte, museus e arquivos digitais. São Paulo: Peirópolis, 2014, p. 266 - 276. 
LEÃO, Lucia (Org.). Derivas: cartografias do ciberespaço. São Paulo, SP: Annablume: Ed. SENAC São Paulo, 2004.

LÉVY, Pierre. Cibercultura. 2. ed. São Paulo: Ed. 34, 2000, p. 17.

LÉVY, Pierre. As tecnologias da inteligência: o futuro do pensamento na era da informática. 1. ed. Rio de Janeiro: Ed. 34, 1993.

LIPOVETSKY, Gilles; SERROY, Jean. A tela global: mídias culturais e cinema na era hipermoderna. Porto Alegre: Sulina, 2009.

MALRAUX, André. Le musée imaginaire. Paris: Gallimard, 2010.

PLAZA, Julio. Arte e interatividade: autor-obra-recepção. ARS (São Paulo), v. 1, n. 2, p. 9-29, 2003.

SALLES, Cecília Almeida. Desafios da arte contemporânea e a crítica de processos criativos. In: Congresso Internacional da Associação de Pesquisadores em Crítica Genética: materialidade e virtualidade no processo de Criação, X Edição, Porto Alegre, RS, 2010. Anais. 2012. p. 519-527.

SALLES, Cecilia Almeida; CARDOSO, Daniel Ribeiro. Crítica genética em expansão. Ciência $e$ cultura, v. 59, n. 1, 2007, p. 44-47. 